Fecha de recepción: febrero 2013 Fecha de aceptación: julio 2013 Versión final: diciembre 2014

\section{Mediatización y diferencia. La búsqueda de la forma para una puesta en escena de Acreedores de Strindberg}

Marcelo Velázquez *

Resumen: Strindberg escribió Acreedores en 1888. No escribió para su tiempo sino para los venideros. El gran problema de Acreedores es discursivo. Adolfo, Tekla y Gustavo, emprenden una "guerra de cerebros", una lucha psicológica y a puro lenguaje. Arrojados al mundo y en la imposibilidad de decir la realidad quedan atrapados en esa "cárcel del lenguaje", que también es la nuestra. Esta nueva puesta en escena de Acreedores pretende un corrimiento de los cánones tradicionales del realismo y del naturalismo estéticos en los que se ha categorizado al autor y a parte de su obra. Si en Acreedores se plantea la pregunta acerca de la forma del arte, esta pregunta aún nos guía: ¿Cuál es la forma contemporánea para esta obra de 1888 ? ¿Cuál es la forma que le corresponde al arte de nuestro tiempo? Aventuramos en los signos de la puesta en escena algunas respuestas: la inclusión. Si Strindberg produce inmerso en una gran crisis finisecular de la representación, la propuesta es desmontar la obra para desligarla de lo representativo y hacer visible y no ocultar los hilos que construyen la representación. Así leemos Acreedores, después de más de un siglo de su escritura, y es nuestro modo de acercarnos a su modernidad.

Palabras claves: crisis del realismo - teatro argentino contemporáneo - versión de los clásicos.

[Resúmenes en inglés y portugués en la página 68]

${ }^{(*)}$ Actor, director y docente. Se formó en la Escuela de Teatro de Alejandra Boero y egresó como Licenciado en Letras de la Facultad de Filosofía y Letras de la Universidad de Buenos Aires. Se desempeña como docente de teatro en el Estudio de La Compañía de Teatro La Muda con sede en Del Borde Espacio Teatral, en el Departamento de Artes Dramáticas del IUNA y en diversos establecimientos educativos.

La propuesta de este trabajo es sintetizar y sistematizar apuntes de director sobre la puesta en escena de la obra Acreedores (1888-1889) del dramaturgo sueco August Strindberg presentada en Del Borde Espacio Teatral de la ciudad de Buenos Aires durante las temporadas 2009 y 2010, bajo mi dirección ${ }^{1}$. Por lo tanto, el objetivo no es realizar un trabajo analítico sobre la obra de Strindberg, que cuenta con una amplia bibliografía al respecto, sino problematizar aspectos relacionados con la obra en función de las decisiones estéticas tomadas desde esta dirección para su puesta en escena. En este sentido, se trata de la 
construcción de un metalenguaje que vuelve sobre tantas huellas dejadas en el tránsito de la pieza desde fines del siglo XIX hasta nuestra contemporaneidad. ¿Cuál es la lectura que ejercemos sobre esos trazos inevitables?: un ejercicio de lectura que acentuará sus marcas.

\section{El problema de la lengua / El problema del discurso}

En la génesis del trabajo, para arribar a la puesta en escena de Acreedores, se realizó un estudio exhaustivo del texto en sus principales versiones en castellano, en una traducción al inglés y en otra al francés, y se contó, además, con la colaboración de un especialista en la lengua original de Strindberg, hasta la versión definitiva que consideramos apropiada para su presentación en Buenos Aires y con la modalidad propia del castellano rioplatense. En este punto, vale aclarar que la lengua sueca posee tres modalidades para indicar la segunda persona: una modalidad informal, que se corresponde con el voseo rioplatense; una formal, equivalente al usted, y una tercera modalidad, intermedia entre el vos y el usted, que no existe en el castellano. Este detalle es relevante para la consideración del texto, y de algunas significaciones, ya que determina el trato entre los personajes de la pieza. Optamos por la utilización del voseo, excepto en determinados pasajes en los que el personaje de Tekla se dirige a su marido utilizando el usted y que implica para los versionistas un trato entre cariñoso y seductor, reconocible en las modalidades de nuestra lengua. Ejemplo:

TEKLA: ¡Pero, a ver, hermanito, dígame qué es lo que estuvo haciendo para entretenerse mientras su gatita estaba afuera!

[...]

¡Pero si se puso colorado! ¿Mi hermanito no me estará contando alguna mentirita no? ¡Vamos, cuéntele a su gatita lo que está pensando!

Pero el gran problema de Acreedores es discursivo. Adolfo, Tekla y Gustavo, las criaturas de Strindberg, emprenden una "guerra de cerebros", una lucha psicológica y a puro lenguaje. Arrojados al mundo y en la imposibilidad de decir la realidad quedan atrapados en esa "cárcel del lenguaje", al decir de Frederic Jameson. Asumimos para la puesta en escena de la obra esta problemática y la adoptamos como hipótesis de trabajo en el sentido en que lo piensan las filosofías del giro lingüístico:

Dentro de esta denominación se agrupan los aportes de diferentes autores y corrientes filosóficas que coinciden en señalar que el lenguaje no es un mero medio entre el sujeto y la realidad, ni tampoco un vehículo transparente o elemento accesorio para reflejar las representaciones del pensamiento, sino que posee una entidad propia que impone sus límites, y determina en cierta manera, tanto al pensamiento como a la realidad; por lo tanto es más productivo abocarse a la investigación del lenguaje que a la del mundo incierto de los contenidos psicológicos (Alegre, 2006). 
Si el lenguaje no tiene otra posibilidad que hablar de sí mismo, leemos Acreedores de Strindberg como una construcción discursiva que pone en escena un aparato retórico propio del universo de fines del siglo XIX. Este aparato da cuenta de la profundización en el conocimiento de la propia naturaleza humana e involucra: la literatura naturalista de las décadas de 1880 y primeros años de la de 1890 (Zola, Maupassant, entre otros) que ya había subrayado la importancia que los condicionantes biológicos, fisiológicos y sociales tenían en la conducta humana; temas como la condición femenina, el adulterio y las relaciones entre los sexos; la obsesión por los complejos de pecado y culpa, y por los estados patológicos de la mente; el interés por la histeria, el suicidio, la criminalidad (sobre todo, a raíz de los trabajos de Cesare Lombroso, 1835-1909) y la psicopatología sexual; los estudios de Mendel sobre la herencia y el inicio de la genética; la relaciones que pudieran existir entre el cuerpo y la mente; el interés en el comportamiento neurótico -uno de los temas preferidos de la cultura del fin de siglo-; los descubrimientos de Charcot que preanuncian la revolución freudiana. Lo que sucedía era que la sociedad comenzaba a conocer aspectos de la naturaleza biológica y psíquica del hombre previamente ocultados y silenciados por la ignorancia, las convenciones o la hipocresía. A ese conocimiento contribuyó, decisivamente, la ciencia.

La decisión es, entonces, para la puesta en escena de Acreedores, mostrar los hilos de construcción del lenguaje científico en el que Strindberg y sus contemporáneos confiaban y mostrarlos como meros dispositivos de lenguaje que cada época crea. ¿Cómo traer a estos comienzos del siglo XXI temáticas y problemáticas que Acreedores plantea y que, en muchos casos, han sido confirmadas o superadas durante el transcurso del siglo XX? Por lo tanto, el primer gesto para esta versión de Acreedores fue distanciar el lenguaje cientificista quitándole poder referencial y vaciándolo de validez objetiva. Pero, al mismo tiempo, indagar en el lenguaje cientificista contemporáneo, en esa ilusión de cientificismo que también nos toca crear en esta época. Pensamos, en este sentido, que el equivalente de la evolución de la ciencia de finales del siglo XIX tiene su correlato en nuestra contemporaneidad con la evolución tecno-científica. Hablar hoy de evolución de la ciencia es hablar de tecnología. Y la tecnología propiciará la construcción de un nuevo lenguaje para nuestra época que se evidencia como una nueva utopía: la utopía tecnológica.

\section{El problema de la forma}

En continuidad con lo anterior, nos preguntamos, entonces, cuál es la forma contemporánea para esta obra de 1888, cuál es la forma que le corresponde al arte de nuestro tiempo. Si en Acreedores se plantea la pregunta acerca de la forma del arte, esta pregunta guió nuestra puesta en escena. Es así que se decidió la inclusión de algunos recursos que provee la tecnología contemporánea: la proyección de imágenes que crean un nuevo lenguaje y que posibilitan una apertura discursiva que se dirige, sin embargo -en consonancia con las filosofías del giro lingüístico- hacia el propio discurso de la obra, en un movimiento endogámico que contribuye a la anulación de todo referente externo y quitan la posibilidad de construcción de una ilusión realista. Las imágenes proyectadas generan un espacio 
otro que incluye escenas imaginarias que no están presentes en la propuesta textual y que crean otra lógica narrativa superpuesta y contaminante; escenas virtuales no representadas o que se desarrollan en un afuera de la escena (de acuerdo con la lógica realista propia de la dramaturgia de finales del siglo XIX), que se hacen presentes en la proyección y, por lo tanto, forman parte de la totalidad del discurso de la puesta; representaciones de algunos cuadros pintados por Strindberg que insinúan un espacio otro, pero que también se vuelven hacia adentro ya que se trata de la representación de la representación, es decir, la representación en imágenes de un cuadro del autor de la obra que se está representando en un diálogo constante entre "obra" y "obra". De la misma manera que lo hace Pasolini en su obra Calderón (1987) donde no sólo titula la pieza con el nombre del autor de la pieza de base sobre la cual realiza su trabajo intertextual ( La vida es sueño), sino que también incluye en su obra la representación del paradigmático cuadro Las Meninas en el cual se observa a Diego de Velázquez, el pintor-autor, pintando un cuadro y pintándose a sí mismo. Así, tenemos la recursividad de la recursividad como modelo para el trabajo de puesta en escena de Acreedores.

Sumando a lo anterior, la puesta en escena traslada a la pantalla la contundente y problemática última escena de Acreedores. Para la puesta en escena consideramos que ese final que propone la obra de Strindberg posee una carga melodramática propia de las estéticas de fin del siglo XIX, por lo cual, y desde este punto de vista, contemporáneamente resultaría irrepresentable. El final de la obra, entonces, es propuesto como el final de una película (la que se inicia con la primera imagen donde se presenta a los personajes de la obra) cuyos espectadores son los mismos actores-personajes y, por supuesto, el público asistente a la sala que mira a los personajes-actores mirando el final de la obra.

Por consiguiente, esta nueva puesta en escena de Acreedores pretende un corrimiento de los cánones tradicionales del realismo y del naturalismo estéticos en los que se ha categorizado al autor y a parte de su obra. Si Strindberg produce inmerso en una gran crisis finisecular de la representación, la propuesta es, entonces, desmontar la obra para desligarla de lo representativo y, en este juego, hacer visible y no ocultar los hilos que construyen la representación.

En este juego de lectura de la representación que habla de la representación se suma en la propuesta un marco introductorio que pone en evidencia una reflexión sobre el teatro y sus posibilidades en cada época. Si decíamos que, contemporáneamente, el lenguaje sólo puede hablar sobre el lenguaje, entonces, el teatro sólo puede hablar de sí mismo. Reflexión y praxis que el mismo Strindberg realizó con gran profundidad en su propio y pequeño teatro -el Teatro Íntimo- innovando el arte teatral de su tiempo y de los venideros. Este marco introductorio - con la voz en off del actor, director y dramaturgo José María Muscari (artista polémico, altamente autoreferencial y con una producción muy particular en nuestra escena contemporánea) - parafrasea el comienzo de la obra Calderón de Pier Paolo Pasolini (1987) donde un Locutor viene en nombre del autor (¿Pasolini? ¿Calderón de la Barca?), para dar cuenta, explicar y justificar - gesto que no puede ser leído más que irónicamente- lo que se va a presenciar en escena. Muscari, a través de su voz, se constituye en un personaje autoenunciado que participará del juego discursivo dirigiéndose a los espectadores presentes en el teatro y evidenciando el propio mecanismo representativo 
y poniendo, por lo tanto, en crisis la propia representación. De la misma manera en que, para pensar el teatro, articula el pasado de 1888 con nuestro presente. Se equiparan así, dos finales de siglo que plantearían cuestiones en común. La pregunta por la forma, entonces, también es una pregunta que nos compromete como artistas en el presente y pone en diálogo las estéticas contemporáneas con las estéticas del pasado.

Además, y para finalizar, aventuramos en otros signos de la puesta en escena algunas respuestas que son nuestro modo de entender la pieza: la inclusión de elementos que interrumpen la acción, la potencian y se suman para anular toda pretensión de ilusión realista, un espacio despojado, mínimo, que derriba la posibilidad de los referentes, una actuación distanciada y apoyada en algunos códigos del melodrama y del relato de suspenso, la estilización de la moda en el vestir de finales del siglo XIX que se contrapone a los recursos tecnológicos, los signos sonoros y musicales anacrónicos.

Estas mediaciones y la mediatización pretenden dar cuenta en esta nueva versión de la obra de Strindberg, a más de un siglo de su escritura, de una lectura contemporánea que relee las instancias estéticas del pasado en un movimiento de repetición (volver con una obra de fines del siglo XIX) atravesada por las huellas de todo el tiempo transcurrido, que esta puesta en escena intenta no eludir, y que marca su diferencia. Al decir de Gilles Deleuze: "Desde todo punto de vista, la repetición es la transgresión. Pone la ley en tela de juicio, denuncia su carácter nominal o general, a favor de una realidad más profunda y más artística" (Deleuze, 2006). Así leemos Acreedores y es nuestro modo de acercarnos a su modernidad.

\section{Notas}

1. El espectáculo Acreedores/Strindberg realizó 52 funciones durante las temporadas 2009 y 2010 en Del Borde Espacio Teatral de la ciudad de Buenos Aires. El espectáculo contó con una asistencia de público de alrededor de dos mil espectadores en la totalidad de sus funciones y recibió dos nominaciones para el premio A.C.E. (Asociación de Cronistas del Espectáculo) en los rubros: Revelación masculina por la dirección y Mejor espectáculo de teatro alternativo. La ficha técnica del espectáculo, fotografías, vídeos y notas de prensa pueden verse en: www.acreedores-strindberg.blogspot.com

\section{Referencias Bibliográficas}

Alegre, J. R. (2006). Giro lingüístico y corrientes actuales de la filosofía. Influencias wittgensteinianas. Instituto de Filosofía, Facultad de Humanidades, UNNE, Resistencia, Chaco.

Deleuze, G. (2006). Diferencia y repetición. Buenos Aires: Amorrortu.

Pasolini, P. P. (1987). Calderón. Barcelona: Icaria Editorial.

Strindberg, A. (2008). Los camaradas. El padre. Señorita Julia. Acreedores. Buenos Aires: Losada. 


\section{Bibliografía}

Alegre, J. R. (2006). Giro lingüístico y corrientes actuales de la filosofía. Influencias wittgensteinianas. Instituto de Filosofía, Facultad de Humanidades, UNNE, Resistencia, Chaco. Deleuze, G. (2006). Diferencia y repetición. Buenos Aires: Amorrortu. Foucault, M. (2002). Las palabras y las cosas. Buenos Aires: Siglo XXI editores. Pasolini, P. P. (1987). Calderón. Barcelona: Icaria Editorial. Scavino, D. (2007). La filosofía actual. Pensar sin certezas. Buenos Aires: Paidós. Strindberg, A. (2008). Los camaradas. El padre. Señorita Julia. Acreedores. Buenos Aires: Losada.

Summary: Strindberg wrote Creditors in 1888 . He didn't wrote for his time but to come. The big problem in Creditors is a discursive one. Adolfo, Tekla and Gustavo, wage a "war of minds" a psychological struggle and purely spoken. Thrown into the world and unable to tell reality they get trapped in this "prison of language", which is also ours. This new staging of Creditors seeks a shift from the traditional canons of aesthetic realism and naturalism in which the author has been categorized as part of his work. If Creditors raises the question about the art form, this question still guides us: What is the contemporary form for this play of 1888 ? What is the form that corresponds to the art of our time? We ventured some answers in the signs of staging: inclusion. If Strindberg produces immersed in a great crisis of representation, the proposal is to remove the work to separate it from the visible representative and do not hide the wires that make up the representation. Thus we read Creditors, after more than a century of its writing, and it is our way of approaching modernity.

Keywords: classics version - contemporary argentine theater - realism crisis.

Resumo: Strindberg escreveu Acreedores em 1888. Não escreveu para seu tempo, senão para os seguintes. O grande problema de Acreedores é discursivo. Adolfo, Tekla e Gustavo, empreendem uma "guerra de cérebros", uma luta psicológica e a pura linguagem. Lançados ao mundo e na impossibilidade de dizer a realidade ficam atrapalhados nessa "cadeia da linguagem" que também é a nossa. Esta nova posta em cena de Acreedores pretende um translado dos cânones tradicionais do realismo e do naturalismo estéticos nos que se categorizou ao autor e a uma parte da sua obra. Se em Acreedores se esboça a pergunta sobre a forma da arte; esta pergunta ainda nos guia: ¿Qual é a forma contemporânea para esta obra de 1888? ¿Qual é a forma que lhe corresponde à arte do nosso tempo? Aventuramos em signos da posta em cena algumas respostas: a inclusão. Se Strindberg produz imerso numa grande crise de fim de século da representação, a proposta é desmontar a obra para desligá-la do representativo e fazer visível e não ocultar os fios que constroem a representação. Assim lemos Acreedores, depois de mais de um século da sua escritura, e é nosso modo de nos acercar a sua modernidade.

Palavras chave: crise do realismo - teatro argentino contemporâneo - versão dos clássicos . 